\title{
Paula L. Aymer
}

Evangelical Awakenings in the Anglophone Caribbean: Studies from Grenada and Barbados. Basingstoke, U.K.: Palgrave Macmillan, 2016. xxi + 216 pp. (Cloth US\$105.00)

Evangelical Awakenings in the Anglophone Caribbean offers a detailed overview of the establishment of evangelical churches in the English-speaking Caribbean with special attention to the islands of Barbados and Grenada. Paula Aymer's exacting and empathetic scholarship gives ample attention to the historical context as well as to the theological underpinnings of the evangelical movement. She also highlights the pivotal role of women in the growth of evangelical churches.

This study is based on more than six years of fieldwork. Aymer participated in multiple religious services, interviewed numerous pastors and converts, examined missionary journals and annual reports, and looked through locallyproduced weekly newspapers which, she found, provided much valuable information. Her research spans three centuries. She compares these nineteenthcentury conversions to those of North American Pentecostalism in the midtwentieth and early twenty-first centuries, documenting both the motivations behind them and the methods for achieving them.

While Aymer's main focus is on the islands of Grenada and Barbados, she gives attention to other Eastern Caribbean islands such as Trinidad. She shows how changes in theological positions and organizational strategies impacted the spread of Christianity in the region. As a sociologist, she stresses the impact of organizations. She adopts a conflict model, which, she contends, accounts for the success of Methodism in the nineteenth century and the triumph of Pentecostalism in the twenty-first.

Chapter 1 gives a brief sociohistorical overview of Protestant missions to the Caribbean from 1800 onward. Chapter 2 shows how race, color, and class distinctions became embedded in Wesleyan missionary activities of the nineteenth century. The third chapter documents the energetic collaboration among Pentecostal pastors and highlights their exuberant forms of worship. Chapter 4 looks at the twentieth-century Caribbean, showcasing the political and collaborative arrangements that North Americans launched in their missionary campaigns to the eastern Caribbean. Chapter 5 focuses on infant baptism. In the nineteenth century, the Anglican Church withheld baptism from the children of enslaved blacks. By the twentieth century, infant baptism had lost its significance, and among evangelicals had been replaced by "baptism of the Holy Spirit." Aymer astutely observes that Caribbean Pentecostals have renegotiated the cultural values ascribed to motherhood and that they now

(C) STEPHEN D. GLAZIER, 2018 | DOI: $10.1163 / 22134360-09201044$

This is an open access article distributed under the terms of the prevailing CC-BY-NC license 
welcome unmarried women and their children. Aymer also emphasizes that women's work is crucial to congregational ministries: music, youth work, visitations, and fund raising. Women also act as "prayer warriors" and Bible study leaders. Chapter 6 examines connections between social mobility and churchsponsored educational institutions. Twenty-first-century Pentecostal churches, for example, are still led by pastors educated in Bible colleges supported by North American Pentecostals.

Aymer's coverage of the nineteenth century is exemplary. She argues that nineteenth-century Methodists in the Eastern Caribbean thrived on their theological differences. Church schisms, she suggests, led to the creation of new churches, which intensified commitment to existing religious organizations. While acknowledging that Barbados and Grenada had very different histories, she demonstrates that with respect to religion the two islands had much in common.

Aymer poses important questions concerning evangelical religions in the Caribbean: How did Caribbean peoples assess evangelicals? What did Caribbean peoples derive from the efforts of foreign missionaries? How was evangelical theology reworked to meet the needs of the poor? And how have Caribbean people emerged from a long history of suffering and exclusion to embrace evangelicalism? As she observes, few scholarly accounts have been written from the perspective of the converted. While the people of the Anglophone Caribbean have been changed by Pentecostalism, they have also altered Pentecostalism to meet their own needs. The religion can no longer be labeled "Pentecostalism" but, as Aymer contends, should more accurately be labeled "Caribbean Pentecostalism."

\section{Stephen D. Glazier}

HRAF, Yale University

stephen.glazier@yale.edu 